\title{
Probiotics as alternatives to antibiotics in treating post-weaning diarrhoea in pigs: Review paper
}

\author{
P. Bogere ${ }^{1}$, Y.J. Choi ${ }^{2}$ \& J. Heo ${ }^{2 \#}$ \\ ${ }^{1}$ Graduate School of Agricultural Convergence Technology, Chonbuk National University, Jeonju 54896, \\ Republic of Korea \\ ${ }^{2}$ International Agricultural Development and Cooperation Centre, Chonbuk National University, Jeonju 54896, \\ Republic of Korea
}

(Received 26 November 2018; Accepted 5 March 2019; First published online 10 May 2019)

\author{
Copyright resides with the authors in terms of the Creative Commons Attribution 4.0 South African License. \\ See: http://creativecommons.org/licenses/by/4.0/za \\ Condition of use: The user may copy, distribute, transmit and adapt the work, but must recognize the authors and \\ the South African Journal of Animal Science
}

\begin{abstract}
The use of antibiotics to prevent post-weaning diarrhoea (PWD) in pigs has faced a setback owing to the associated antibiotic resistance in pigs and in the human populace that consumes the pork. In fact, antibiotic resistance that originates from the food chain is estimated to cause around 700,000 deaths globally each year. Consequently, scientists and researchers have suggested possible alternatives to antibiotics in pig diets. The chief of these has been the use of probiotics. The authors reviewed the literature on the use of probiotics as an alternative to antibiotics in treating PWD in pigs. It is clear that because of pathogenic Escherichia coli PWD continues to be a challenge to profitable swine production. The vast number of studies that was reviewed, point to the beneficial effects of probiotic supplementation on reducing the severity and incidence of PWD. However, some studies report inconsistencies to the general hypothesis. The majority of the microorganisms used as probiotics in the studies belong to the genera Lactobacilli, Bacillus, Bifidobacterium, Enterococcus, probiotic Escherichia coli, and Saccharomyces. The review also revealed that the bacterial strains that are used as probiotics are given individually or as combinations of multiple strains, and at various dosages, yielding varied results in each case. Interestingly, the authors observed wide disparities in the onset of probiotic supplementation and duration of the treatment to attain the results. Hence there is a need to standardize supplementation strategies, including dosage, onset and duration of treatment for probiotics. Furthermore, many of the in vivo studies that revealed positive effects of probiotics on diarrhoea and other production parameters were carried out in more controlled environments. The authors therefore suggest that more field studies in more natural and commercial farm settings should be conducted to augment the literature in relation to the use of probiotics as alternatives to antibiotics in treating PWD.
\end{abstract}

Keywords: antimicrobial resistance, directly-fed microorganisms, post-weaning diarrhoea, swine diets

\# Corresponding author: jyheobio@gmail.com

\section{Introduction}

Post-weaning diarrhoea (PWD) has been documented as a major economic disease that affects swine farmers globally. PWD causes plenty of losses to the farmers through increased deaths, morbidities, lowered productivity of surviving pigs, and the costs of treatment protocols (Zhao \& Kim, 2015). Generally, piglets are affected during the first two weeks post weaning. This is a stressful period that is characterized by separation from the sow, changes in diet, adaptation to new environments, mixing of litters, and small intestine histological changes. All these changes may affect the immune response, predisposing the piglets to gastrointestinal tract (GIT) dysfunction (Gresse et al., 2017; Rhouma et al., 2017). Moreover, it is widely accepted that dietary transition, coupled with environmental changes, as occurs during weaning, modifies the piglets' intestinal microbiome and this is believed to be connected with the development of observed diarrhoea and other enteric infections (Lallès et al., 2007). PWD is associated with the colonization and proliferation of enterotoxigenic Escherichia coli (ETEC) strains in the pig intestine (Dubreuil, 2017; Pan et al., 2017; Rhouma et al., 2017). These strains function through producing enterotoxins that act on the small 
intestines and lead to the secretion of fluids and electrolytes, causing diarrhoea. To curb PWD and other opportunistic stressors and improve the growth of piglets, there has been widespread use of antibiotic feed additives (Pan et al., 2017; Reid \& Friendship, 2002). However, the prolonged and irrational use of these antibiotics in the food chain has led to bacterial resistance in the animals and in consumers of their products. This resistance has led to the hindered administration of effective therapies, thereby increasing morbidities and mortalities (Daudelin et al., 2011; Yi et al., 2016). The resistance in humans stems from the fact that antibiotic molecules used in animals have a generic resemblance to those applied in humans (Liao \& Nyachoti, 2017). Thus, the use of antibiotics has been banned in many regions of the world, such as the European Union in 2006 (Chen et al., 2005), or its use been limited, such as in the US, where the Food and Drug Administration (FDA) has given approval to very few antibiotics. Moreover, there is now a slowed production of new antibiotics on the market (Yi et al., 2016). This cascade of events around the use of antibiotics instigated researchers to come up with alternatives that could be applied in swine diets to prevent PWD, improve feed efficiency, promote growth, reduce odour, and ultimately confer health benefits to swine (Vondruskova et al., 2010). Thus, various naturally occurring materials have been suggested and applied in swine diets, and their effects have been investigated in vitro and in vivo. Alternative molecules that have been used include organic acids, probiotics, prebiotics, enzymes, medium chain fatty acids, essential oils, yeasts, zinc, and plant extracts. These have all proved to be effective replacements for antibiotics (Vondruskova et al., 2010; Omonijo et al., 2017). However, among all these alternatives, probiotics have been widely and extensively used as better replacements for the subtherapeutic antibiotic doses that are often used in curbing PWD. A summary of microorganisms that are commonly used as probiotics is shown in Table 1. In this article, the authors review and summarize the research outputs and literature pertaining to the use of probiotics in the prevention and treatment of PWD in swine.

\section{Post-weaning Diarrhoea in Piglets}

Post-weaning diarrhoea that is caused by ETEC is a detrimental condition that often occurs in weaned pigs two weeks post separation from the sows and is characterized by watery faeces, sudden deaths, dehydration, and retarded growth in survivors (Lauridsen, 2017; Rhouma et al., 2017). Although ETEC is widely implicated in PWD, the condition is a multifactorial phenomenon whose exact cause has yet to be ascertained. In many scenarios, its occurrence has been associated with the interaction between the sow, piglet, pen environment, E. coli, and the overall farm management (Laine et al., 2008; Rhouma et al., 2017). Thus, the factors that influence the onset of PWD can be categorized broadly into predisposing, contributing, and determining factors. Among the predisposing factors are genetic predisposition, immunity, weaning weight, and age. Studies have indicated that low weaning weight and age, coupled with impaired preweaning health, contribute greatly to PWD (Laine et al., 2008; Rhouma et al., 2017). Additionally, early weaned piglets have been demonstrated to have impaired immune functions and this further predisposes them to diarrhoea development during the weaning period. Further, owing to the immaturity of the intestinal immunity and the loss of the passive immunity as a result of the lack of the IgA-rich sow's milk, piglets become susceptible to many opportunistic pathogens in their gut (Laine et al., 2008; Heo et al., 2013; Rhouma et al., 2017). The proliferation of strains of $\beta$-haemolytic ETEC (strains expressing F4 or F18 fimbriae) in the small intestines of piglets is widely associated with PWD and, as a crucial step in its pathogenesis, the interaction between the fimbria and receptor enables the pathogen to fully colonize the small intestines (Frydendahl et al., 2003; Fairbrother et al., 2005). Thus, fimbriae F4 and F18 are crucial to the colonization of small intestines by pathogenic strains that cause post-weaning diarrhoea. However, the presence or absence of intestinal receptors for F4/F18 is controlled genetically and determines whether the piglets are susceptible (Frydendahl et al., 2003). Other factors that have been implicated in the predisposition of piglets to PWD and other microbial infections include litter size, parity of the sow, postpartum dysgalactia and other piglet associated conditions such as birth order and genotype (Hong et al., 2006).

Moreover, factors that occur immediately after weaning, including housing sanitation, the numbers of piglets per pen, feeding regimes and pig flow systems, contribute greatly to the scourge of PWD. As reviewed by Jayaraman \& Nyachoti (2017), the sanitation status of the swine environment in commercial production has a direct bearing on pig health. In the same paper, it is reported that poor sanitary conditions in a pig farm are a precursor to low inflammation in weaned piglets. Poor sanitary and hygienic situations occur when the pens are not cleaned and disinfected prior to placement and during the rearing period, because of negligent stockmanship and unremoved leftover feed, among others. 
Table 1 Microorganisms commonly used as probiotics in swine nutrition

\begin{tabular}{|c|c|c|c|c|}
\hline Genus & Description & Species & Strain & Reference \\
\hline \multirow{7}{*}{ Lactobacillus } & \multirow{7}{*}{$\begin{array}{l}\text { Gram-positive, produce lactic acid as their end product of carbohydrate } \\
\text { fermentation. Has a large number of species categorized as GRAS }\end{array}$} & L. Plantarum & $\begin{array}{l}\text { ZJ316, DSMZ } \\
\text { 8862/8866, LQ80, } \\
\text { JDFMLP11 }\end{array}$ & $\begin{array}{l}\text { (Heo et al., 2018; } \\
\text { Mizumachi et al., 2009; } \\
\text { Pieper et al., 2011; Suo et } \\
\text { al., 2012) }\end{array}$ \\
\hline & & L. fermentum & 15007 & (Liu et al., 2014) \\
\hline & & L. casei & GG & (Roselli et al., 2005) \\
\hline & & L. acidophilus & C3, NCDC-15 & $\begin{array}{l}\text { (Dowarah, Verma, et al., } \\
\text { 2017a; Giang et al., 2011) }\end{array}$ \\
\hline & & L. brevis & ATCC $8287,1 \mathrm{E} 1$ & $\begin{array}{l}\text { (Gebert et al., 2011; } \\
\text { Lähteinen et al., 2014) }\end{array}$ \\
\hline & & L. salivarius & UCC118 & $\begin{array}{l}\text { (Riboulet-Bisson et al., } \\
\text { 2012) }\end{array}$ \\
\hline & & L. reuteri & $\begin{array}{l}\text { BSA131, } \\
\text { ATCC53608, NCIMB } \\
30242,\end{array}$ & (Hou et al., 2015) \\
\hline \multirow{3}{*}{ Bacillus } & \multirow{3}{*}{$\begin{array}{l}\text { Ubiquitous in the environment, endospore forming and hardy enough to } \\
\text { survive in a variety of foods compared with other probiotic species }\end{array}$} & B. subtlis & $\begin{array}{l}\text { LS 1-2, MA139, M- } \\
1, \text { DSM } 5750\end{array}$ & $\begin{array}{l}\text { (Additives \& Feed, 2011; } \\
\text { Guo et al., 2006; Lee et al., } \\
\text { 2014; Wang et al., 2011) }\end{array}$ \\
\hline & & B. licheniformis & DSM 5749 & (Additives \& Feed, 2011) \\
\hline & & B. cereus & toyoi & (Papatsiros et al., 2011) \\
\hline \multirow{3}{*}{ Bifidobacterium } & \multirow{3}{*}{$\begin{array}{l}\text { Gram-positive, anaerobic ubiquitous inhabitants of the mammalian } \\
\text { mouth, GI tract, and vagina. Being saccharolytic in nature, they } \\
\text { produce acetic and lactic acid without } \mathrm{CO}_{2} \text { production except during } \\
\text { gluconate degradation }\end{array}$} & B. longum & - & $\begin{array}{l}\text { (Brown et al., 1997; Estrada } \\
\text { et al., 2001) }\end{array}$ \\
\hline & & B. animalis & CSCC 1941, MB5 & \\
\hline & & B. lactis & NCC2818 & (Merrifield et al., 2013) \\
\hline $\begin{array}{l}\text { Probiotic } \\
\text { Escherichia coli }\end{array}$ & $\begin{array}{l}\text { Non-pathogenic in nature, a commensal isolate of E. coli and forms a } \\
\text { basis for production of probiotics. Used in the treatment of intestinal } \\
\text { disorders }\end{array}$ & E. coli & $\begin{array}{l}\text { Nissle } 1917 \text { (O6:K5: } \\
\text { H1) }\end{array}$ & $\begin{array}{l}\text { (Duncker et al., 2006; D. } \\
\text { Krause et al., 2010) }\end{array}$ \\
\hline Enterococcus & $\begin{array}{l}\text { Found in the mammalian GIT and on the skin. Belongs to the LAB } \\
\text { group. Has antagonistic properties to harmful bacteria hence used as a } \\
\text { probiotic }\end{array}$ & $\begin{array}{l}\text { Enterococcus } \\
\text { faecium }\end{array}$ & DSM 7134 & (Lojanica et al., 2010) \\
\hline \multirow{2}{*}{ Saccharomyces } & \multirow{2}{*}{$\begin{array}{l}\text { Commonest symbiotic yeast inhabiting the respiratory, gastrointestinal } \\
\text { tract and the vaginal mucosa. Also referred to as brewer's yeast. } \\
\text { Probiotic properties of yeast include antagonizing other } \\
\text { microorganisms such as moulds and bacteria }\end{array}$} & $\begin{array}{l}\text { Saccharomyces } \\
\text { cerevisiae var. } \\
\text { boulardii }\end{array}$ & - & (Badia et al., 2012) \\
\hline & & $\begin{array}{l}\text { Saccharomyces } \\
\text { cerevisiae }\end{array}$ & CNCM I-4407 (SCC) & (Priori et al., 2015) \\
\hline
\end{tabular}

GRAS: Generally regarded as safe, GIT: Gastrointestinal tract, LAB: Lactic acid bacteria 
Poor hygiene allows the proliferation of pathogenic microorganisms in the piglets' environment, which terminally find their way into the gut via the faecal-oral pathway. Post-weaning feeding and feeding regimes have been implicated in PWD, and the sudden change from sow milk to a solid ration, as occurs during weaning, has been demonstrated to reduce villus height while increasing crypt depths in the ileum, leading to diarrhoea (Dong \& Pluske, 2007). Since the piglets are not accustomed to the solid feed that is offered after weaning, there is a reduction in voluntary feed intake, which affects overall nutrient capture and adsorption (Lalles et al., 2007). The scope of this paper does not dwell on the details of feeding in relation to diarrhoea since this has been discussed extensively in other reviews (Dong \& Pluske, 2007; Lalles et al., 2007). However, studies have indicated that farms that fed piglets twice a day with restricted amounts of feed suffered a higher prevalence of PWD compared with farms that provided feed ad libitum to the piglets (Laine et al., 2008; Rhouma et al., 2017).

Escherichia coli is the most abundant aerobic coliform species in the normal colon. However, it has the potential to be an enteric pathogen and cause diarrhoea in the host. The ETEC proliferation in the gut that usually occurs post weaning in pigs is highly responsible for the common intestinal disorder that is designated post-weaning colibacillosis (Wellock et al., 2007). ETEC elicits hypersecretory diarrhoea once their colonies reach enough numbers in the gut, and this lasts for up to 14 days. These E. coli pathogens act through attaching to the small intestinal microvilli and producing enterotoxins that act locally to disrupt the normal functioning of enterocytes. This leads to hypersecretion of water and electrolytes, coupled with impaired absorption and thus the observed severe watery diarrhoea (Nagy \& Fekete, 1999; Wellock et al., 2007). A flow of events that lead to diarrhoea and death is shown in Figure 1 (Fairbrother et al., 2005). Studies have revealed four $E$. coli toxins that interact with the intestines of the weaners. LT enterotoxin (heat labile), STI and STII (heat stable), and Shiga-like exotoxin type 2 variant (SLTIIv) are involved in oedema disease (Madec et al., 2000). E. coli pathogenic strains colonize the gut using fimbriae adhesion factors to produce the exotoxins that are responsible for disease occurrence. The most common fimbriae used by pathogenic E. coli in weaned pigs include F4 (K88) and F18. However, other fimbriae such as F5 (K99), F6 (987P) and F41 are detectable and often associated with E. coli that causes neonatal diarrhoea (Frydendahl, 2002; Nagy \& Fekete, 1999; Fairbrother et al., 2005). Infection of the piglets with ETEC is evidenced by signs that include the loss of body condition, depression, dehydration, lowered feed intake, hampered weight gain, loss of weight, and, ultimately, death (Madec et al., 2000).

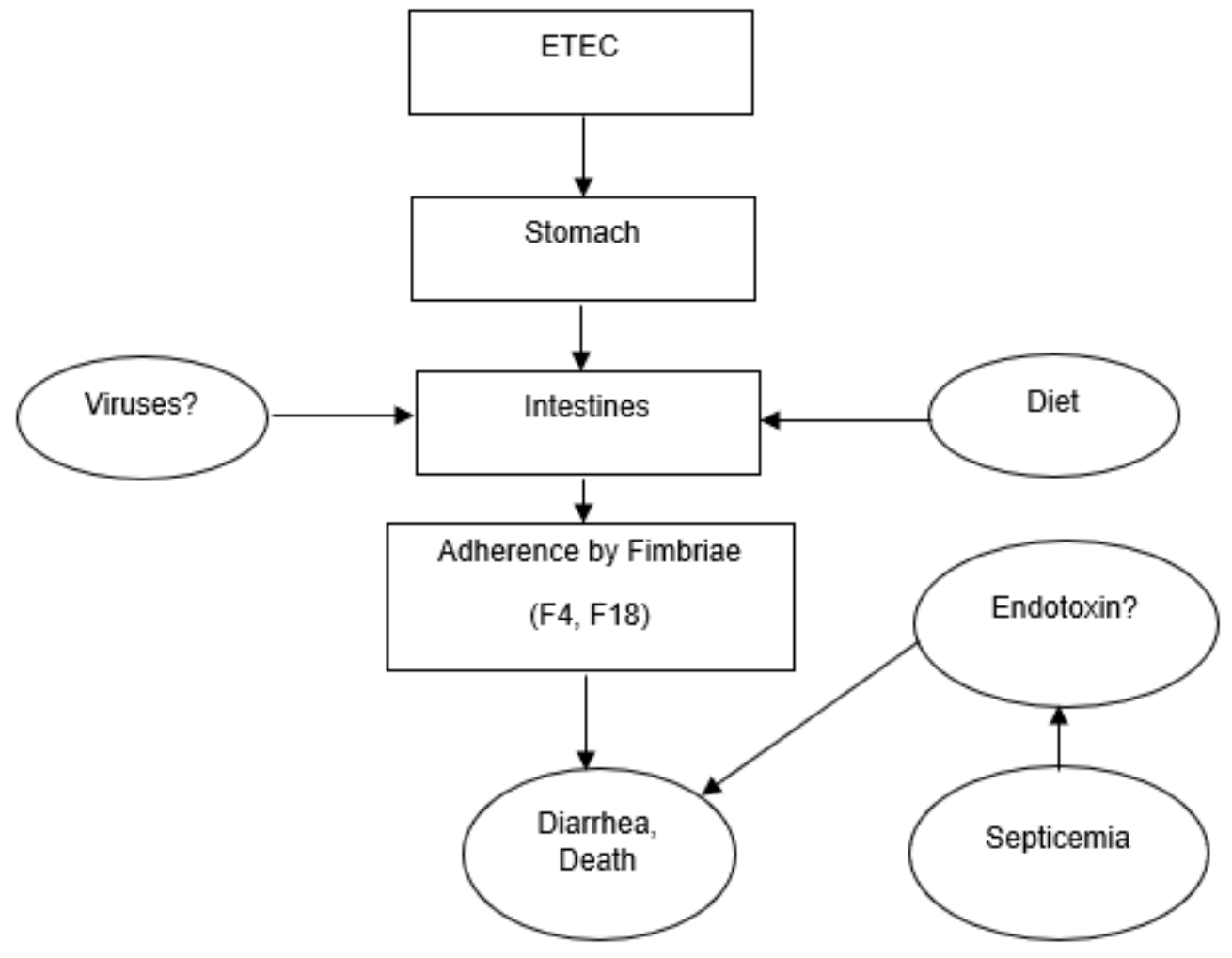

Figure 1 Pathogenesis of diarrhoea due to enterotoxigenic Escherichia coli 


\section{Probiotics Use in Prevention and Control of Post Weaning Diarrhoea}

After the ban on the use of antibiotics in animal feed - which was executed in January 2006 in the EU owing to feared and observed emergence of antibiotic-resistant bacteria (ARBs), coupled with increasing demands from consumers for safe and health foods of animal origin - newer strategies to curb PWD and promote growth have been suggested and tried. Hence, as an alternative to antibiotics, the use of probiotics has gained interest among farmers and researchers in the past couple of years (Dowarah, Verma, et al., 2017b). Probiotics have been defined by FAO as live microorganisms that confer health benefits to the host once ingested in the correct amounts (FAO, 2016). However, in recent years, owing to increasing interest and research on probiotics, the definition has been extended to incorporate microbial and fermentation products. Therefore, probiotics have been defined as concoctions of known viable microbes in adequate numbers that modify the host microflora to confer health benefits (Callaway et al., 2008). These probiotics are in a sense feed additives and are used to modulate gut microbiota of the host while replenishing the intestinal immune system. A number of probiotics, individually or in combination, have been used to prevent and control post-weaning diarrhoea with positive results. (A summary of some is shown in Table 2.) Probiotic preparations that have been used in livestock are always a single species of a microorganism or a mixture of species, for example lactic acid bacteria (LAB), yeasts, Bifidobacterium, Enterococcus and Bacillus (Callaway et al., 2008). Table 3 documents some of the commercial probiotic products on the market that are used by farmers in swine and other livestock.

In a field study, the supplementation of a probiotic combination of Bacillus licheniformis-DSM 5749 and $B$. subtilis-DSM 5750 (1:1) spores to diets of weaners, growers and finishing pigs in a commercial farm revealed lowered incidences of diarrhoea because of $E$. coli in all the groups, and improved other parameters, including feed conversion efficiency, weight gain and carcass quality (Alexopoulos et al., 2004). They demonstrated that the probiotic effects were much more pronounced when medium and high doses were used ( $400 \mathrm{~g} /$ ton of feed equivalent to $1.28 \times 10^{6}$ viable spores per gram of feed and $600 \mathrm{~g} / \mathrm{ton}=1.92 \times$ $10^{6}$ spores per gram, respectively). A study by Zeyner \& Boldt (2006) revealed that daily supplementation of piglets from birth to weaning twice a day with Enterococcus faecium DSM 10663 NCIMB 10415 (EcF) at a dosage of $1.26 \times 10^{9}$ colony forming units (CFU) orally through drenching reduced the percentage of piglets that suffered from diarrhoea and improved their daily weight gain. On the other hand, it was shown in the same study that a glucose-based solution with additional 2.9-5.8 $\times 10^{8}$ CFU of EcF did not have any therapeutic effects once diarrhoea was present. However, the reduction in diarrhoea scores and the percentage of viable piglets that developed diarrhoea post EcF supplementation was convincing enough to conclude that the probiotic stabilized the gut environment, which later translated into improved daily weight gain. Bacteria Enterococcus faecium have been demonstrated to prevent adhesion of the ETEC K88 strain to the intestinal mucous membrane of piglets and its ability to regulate intestinal microbial balance through increasing digestive enzyme activity, improving digestion, feed digestibility and nutrient utilization results into lowered morbidity, mortality and increased performance of farm animals (Vondruskova et al., 2010). In another study, a Lactobacilli complex containing Lactobacillus gasseri, L. reuteri, L. acidophilus and $L$. fermentum (strains not specified in the reference) that were isolated from the digestive tract of a health weaner piglet were demonstrated to reduce the diarrhoea index (66\%) and incidence $(69.1 \%)$ in weaned piglets challenged with E. coli solution (serovars K99, K88 and 987P at the ratio of $1: 1: 1$ ). In the study, three-way crossbred piglets (Duroc $\times$ Landrace $\times$ Yorkshire) weaned at 28 days were fed a basal diet formulated according to the NRC (1998) requirements and the lactobacilli complex as a liquid supplement via water at the inclusion of $0.1 \%(\mathrm{v} / \mathrm{v})$. The $E$. coli challenge was after seven days of probiotic consumption, while diarrhoea scores were recorded a week later. It was observed that the control group registered the first diarrhoea incidence one day post challenge, while in the probiotic group this was seen four days later. This therefore pointed to the possibility of lactobacilli preventing $E$. coli induced diarrhoea before challenge (Huang et al., 2004). Moreover, in the same paper, the probiotic complex significantly $(P<0.01)$ reduced the counts of $E$. coli and other aerobic bacteria, while increasing lactobacilli and anaerobic counts. Probiotic Enterococcus faecium NCIMB 10415 and Bacillus cereus var. toyoi of different ecological origins were studied to assess their impact on swine health and performance. It was established that both molecules reduced the incidence of PWD significantly (Taras et al., 2007). Furthermore, the inclusion of these probiotics in the sow feed was associated with their detection in the piglets' faecal matter even before piglets could access the supplemented diets, which indicated the possibility of vertical transfer via contact with the sow's faeces. In the same study, the ability to reduce the relative magnitude of post-weaning diarrhoea by E. faecium NCIMB 10415 was independent of its concentration in the diet and commencement time for supplementation. 
Table 2 Probiotic combinations shown to have positive effects on the reduction of post-weaning diarrhoea

\begin{tabular}{|c|c|c|c|c|c|c|c|}
\hline Probiotics & Breed & Age & $\begin{array}{l}\text { Weight } \\
(\mathrm{kg})\end{array}$ & Dosage & $\begin{array}{l}\text { Duration } \\
\text {-days } \\
\end{array}$ & $\begin{array}{l}\text { Effect on } \\
\text { diarrhoea }\end{array}$ & Ref \\
\hline Bifidobacterium lactis HN019 & - & 21 days & $5-7$ & $\begin{array}{l}10^{8} \mathrm{CFU} / \mathrm{mL} \\
10 \mathrm{ml} / \text { piglet/day }\end{array}$ & 21 & $\begin{array}{l}\text { Lowered } \\
\text { severity }\end{array}$ & $\begin{array}{l}\text { (Shu et al., } \\
\text { 2001) }\end{array}$ \\
\hline $\begin{array}{l}\text { Bifidobacterium longum subsp. infantis CECT } \\
720+\text { Bifidobacterium animalis subsp. lactis } \\
\text { BPL6 }\end{array}$ & $\mathrm{LW} \times \mathrm{LL}$ & $\begin{array}{l}25-31 \\
\text { days }\end{array}$ & $7.7 \pm 0.28$ & $10^{9} \mathrm{CFU} / 2 \mathrm{~mL}$ & 16 & Decreased & $\begin{array}{l}\text { (Barba-Vidal } \\
\text { et al., 2017) }\end{array}$ \\
\hline $\begin{array}{l}\text { Lactobacillus murinus DPC6002 and DPC6003, } \\
\text { Lactobacillus pentosus DPC6004, Lactobacillus } \\
\text { salivarius DPC6005, and Pediococcus } \\
\text { pentosaceous DPC6006 }\end{array}$ & $\mathrm{LW} \times \mathrm{LL}$ & Weaners & - & $4 \times 10^{10}$ CFU/day & 30 & $\begin{array}{l}\text { Reduced } \\
\text { incidence } \\
\text { and severity }\end{array}$ & $\begin{array}{l}\text { (Casey et al., } \\
\text { 2007) }\end{array}$ \\
\hline $\begin{array}{l}\text { Lactobacillus acidophilus NCDC-15 } \\
\text { Pediococcus acidilactici strain FT28 }\end{array}$ & $\begin{array}{l}\text { Indian } \\
\text { Local×LL }\end{array}$ & 28 days & - & 200 g/pig/day & 180 & $\begin{array}{l}\text { Lowered } \\
\text { scores }(P \\
<0.05)\end{array}$ & $\begin{array}{l}\text { (Dowarah, } \\
\text { Verma, } \\
\text { Agarwal et } \\
\text { al., 2017) }\end{array}$ \\
\hline $\begin{array}{l}\text { LAB complex (Enterococcus faecium } \\
6 H 2, \text { Lactobacillus acidophilus } \\
C 3, \text { Pediococcus pentosaceus D7, L. } \\
\text { plantarum } 1 K 8 \text { and L. plantarum } 3 K 2 \text { ) }\end{array}$ & LLXY & $\begin{array}{l}21-23 \\
\text { days }\end{array}$ & $6.6 \pm 0.5$ & $600 \mathrm{mg} / \mathrm{kg}$ & 35 & $\begin{array}{l}\text { Less affected } \\
\text { in first } 2 \\
\text { weeks }\end{array}$ & $\begin{array}{l}\text { (Giang et al., } \\
\text { 2010) }\end{array}$ \\
\hline $\begin{array}{l}\text { LAB complex (Enterococcus } \\
\text { faecium } 6 \mathrm{H} 2, \text { Lactobacillus } \\
\text { acidophilus } \mathrm{C} 3, \text { Pediococcus pentosaceus D7, } \\
\text { and L. fermentum NC1) + B. subtilis H4 } \\
\text { and Saccharomyces boulardii Sb. }\end{array}$ & LL $\times Y$ & $\begin{array}{l}26-28 \\
\text { days }\end{array}$ & $7.7 \pm 0.9$ & $\begin{array}{l}\text { B. subtilis; } 4-8 \times 10^{11}, \mathrm{~S} \text {. bourlardii; 3- } \\
9 \times 10^{10} \text {, E. faecium; } 4-8 \times 10^{9}, \mathrm{~L} \text {. } \\
\text { acidophilus; } 3-7 \times 10^{9}, \mathrm{P} . \\
\text { pentosaceous } 1.3-8.5 \times 10^{9}, \mathrm{~L} \text {. } \\
\text { fermentum; } 5-7 \times 10^{9} \mathrm{CFU} / \mathrm{mL} \\
\text { Each day } 2 \mathrm{~mL} / \mathrm{kg} \text { of basal diet }\end{array}$ & 35 & $\begin{array}{l}\text { Lower } \\
\text { incidence }\end{array}$ & $\begin{array}{l}\text { (Giang et al., } \\
\text { 2012) }\end{array}$ \\
\hline L. reuteri and L. plantarum complex ${ }^{\mathrm{a}}$ & $L L \times Y \times D$ & 28 days & $7.90 \pm 0.92$ & $0.1 \%\left(1 \times 10^{9} \mathrm{CFU} / \mathrm{kg}\right)$ & 28 & $\begin{array}{l}\text { Lower score } \\
(P<0.05)\end{array}$ & $\begin{array}{l}\text { (Zhao \& Kim, } \\
\text { 2015) }\end{array}$ \\
\hline Lactobacillus rhamnosus GG (ATCC 53103) & $D \times L L \times L W$ & 18 days & $5.3 \pm 0.43$ & $1 \times 10^{10} \mathrm{CFU} / \mathrm{mL}$ & 14 & $\begin{array}{l}\text { Lower } P \\
<0.05\end{array}$ & $\begin{array}{l}\text { (Zhang et al., } \\
\text { 2010) }\end{array}$ \\
\hline
\end{tabular}

${ }^{a}$ Strains not specified in the reference, LL: Landrace, Y: Yorkshire, LW: Large White, D: Duroc, CFU: Colony forming unit 
Table 3 Commercially available probiotics commonly used in pigs and other livestock

\begin{tabular}{|c|c|c|c|c|}
\hline Probiotic name & Composition & Target species & Dosage in pigs & Indication \\
\hline World Labs® & $\begin{array}{l}\text { Lactobacillus casei } \\
\text { Bacillus subtilis } \\
\text { Saccharomyces cerevisiae } \\
\text { Aspergillus oryzae } \\
\text { Streptomyces grieus }\end{array}$ & $\begin{array}{l}\text { Pigs, poultry, } \\
\text { cattle }\end{array}$ & $\begin{array}{l}1 \mathrm{~kg} / \mathrm{ton} \text { of feed } \\
(0.1 \%)\end{array}$ & $\begin{array}{l}\text { Improve FCR, } \\
\text { weight gain, } \\
\text { promote growth and } \\
\text { improve } \\
\text { environmental } \\
\text { livestock farm } \\
\text { Increase milk } \\
\text { production in cattle }\end{array}$ \\
\hline BioPlus 2B® & $\begin{array}{l}\text { Bacillus subtilis DSM } 5750 \\
\text { and Bacillus licheniformis } \\
\text { DSM } 5749\end{array}$ & $\begin{array}{l}\text { Pigs, poultry, } \\
\text { calves, rabbits }\end{array}$ & $\begin{array}{l}1.3 \times 10^{9} \mathrm{CFU} / \mathrm{kg} \\
\text { feed } \\
6.5 \times 10^{8} \mathrm{CFU} / \mathrm{mL} \\
\text { water }\end{array}$ & $\begin{array}{l}\text { Improve ADG, feed } \\
\text { efficiency, growth } \\
\text { promotions, } \\
\text { Decrease in piglet } \\
\text { diarrhoea }\end{array}$ \\
\hline MICROGUARD® & $\begin{array}{l}\text { Bacillus Licheniformis } \\
\text { DSM5749 } \\
\text { Bacillus Megaterum } \\
\text { Bacillus Mesentricus } \\
\text { Bacillus polymyxa } \\
\text { Saccharomyces bourIrdii } \\
\text { Bacillus subtilis }\end{array}$ & Pigs and poultry & $\begin{array}{l}\text { Starter/Sow: } 100 \\
\text { g/ton of feed } \\
\text { Grower/Finisher: } 50 \\
\text { g/ ton of feed }\end{array}$ & $\begin{array}{l}\text { Optimizing gut } \\
\text { integrity, improving } \\
\text { immunity, odour } \\
\text { reduction, } \\
\text { Increasing } \\
\text { absorption in the } \\
\text { intestines (brush } \\
\text { border) }\end{array}$ \\
\hline PrimaLac $®$ & $\begin{array}{l}\text { Lactobacillus acidophilus, } \\
\text { Lactobacillus casei, } \\
\text { Bifidobacterium } \\
\text { thermophilum, and } \\
\text { Enterococcus faecium }\end{array}$ & $\begin{array}{l}\text { Pigs, cattle, } \\
\text { horses, poultry }\end{array}$ & $1.0 \times 10^{8} \mathrm{CFU} / \mathrm{g}$ & $\begin{array}{l}\text { Maintaining an } \\
\text { optimal microbial } \\
\text { balance of } \\
\text { commensal } \\
\text { bacteria against } \\
\text { pathogenic } \\
\text { microbes }\end{array}$ \\
\hline PORCBOOST $^{(B)}$ EB & Bacillus subtilis & $\begin{array}{l}\text { Suckling and } \\
\text { weaned piglets }\end{array}$ & - & $\begin{array}{l}\text { Reduction of E. coli } \\
\text { induced diarrhoea }\end{array}$ \\
\hline Protexin $®$ & $\begin{array}{l}\text { L. debrueckii subsp. } \\
\text { bulgaricus, } L \text {. acidophilus, } L . \\
\text { plantarum, L. rhamnosus, } \\
\text { Bifidobacterium bifidum, } \\
\text { Enterococcus faecium, } \\
\text { Streptococcus thermophilus }\end{array}$ & $\begin{array}{l}\text { Most farm animals } \\
\text { including pigs }\end{array}$ & $\begin{array}{l}\text { Pigs: } 0.5-0.6 \mathrm{~kg} / \mathrm{ton} \\
\text { of feed } \\
\text { Piglets: } 1.4 \mathrm{~kg} / \mathrm{ton} \\
\text { of feed }\end{array}$ & $\begin{array}{l}\text { Improve growth, } \\
\text { feed utilization, } \\
\text { reduced intestinal } \\
\text { dysfunction, }\end{array}$ \\
\hline ENVIVA MPI® & $\begin{array}{l}\text { Lactobacillus rhamnosus and } \\
\text { Lactobacillus farciminis }\end{array}$ & Pigs & $1 \mathrm{~kg} / \mathrm{ton}$ of feed & $\begin{array}{l}\text { Support gut health } \\
\text { improve body } \\
\text { weight gain }\end{array}$ \\
\hline B. infantis IM1® & $\begin{array}{l}\text { Bifidobacterium } \\
\text { longum subsp. infantis CECT } \\
7210\end{array}$ & Pigs, Human & $\begin{array}{l}10^{9} \text { CFU supplied in } \\
2 \mathrm{~mL} \text { solution }\end{array}$ & $\begin{array}{l}\text { Enhancement of } \\
\text { gut health and } \\
\text { intestinal immunity }\end{array}$ \\
\hline
\end{tabular}

Most of these are commercial products and the strains have not been specified in the references

(Alexopoulos et al., 2004; Barba-Vidal et al., 2017; FAO, 2016)

FCR: Feed conversion ratio, ADG: Average daily gain, CFU: Colony forming units

A probiotic product that contained viable spores of Bacillus licheniformis was tested for its efficacy on PWD in a low health status farm after 28 days. The probiotic was administered at two inclusion levels, namely $10^{6}$ and $10^{7}$ viable spores of $B$. licheniformis per gram of feed. In the same study, one group of piglets was offered feed supplemented with $10^{6}$ viable spores of Bacillus toyoi. The results showed that all groups that received probiotic supplements had reduced severity and incidence of diarrhoea, coupled with lower morbidity and mortality compared with the controls (Kyriakis et al., 1999). The group of piglets that received higher doses of $B$. licheniformis $\left(10^{7}\right.$ viable spores per gram of feed) was associated with better performance. Supplementation of weaned barrow diets with Lactobacillus rhamnosus GG ATCC 53103 after experimental infection with Escherichia coli K88 reduced diarrhoea incidences, lowered faecal coliform counts, and increased lactobacilli counts. The barrows were a cross of Duroc, Landrace and Yorkshire, weighing $5.3 \pm 0.43 \mathrm{~kg}$, and weaned at 18 days. In addition to the standard weaner diet, which comprises 
mainly $22.3 \%$ crude protein and $14.0 \mathrm{MJ}$ dietary energy/kg, the piglets were orally administered $10 \mathrm{~mL}$ of $10^{10}$ CFU LGG probiotic solution and seven days later were challenged with ETEC to induce diarrhoea. It was shown that LGG led to increased concentrations of secretory immunoglobulin $A$ in the jejunum and ileum, and high titers of the tumour necrosis factor TNF- $\alpha$ alongside the reduced diarrhoea scores (Zhang et al., 2010). Another study showed that inclusion of a direct fed probiotic complex of Lactobacillus reuteri and Lactobacillus plantarum, added at $0.1 \%\left(1 \times 10^{9} \mathrm{CFU} / \mathrm{kg}\right)$, elevated the numbers of lactobacillus in faeces, reduced diarrhoea, malodour emission, and Escherichia coli shading in weaners (Zhao \& Kim, 2015). In a pig model of intestinal infection with porcine enterotoxigenic Escherichia coli Abbotstown (EcA), it was revealed that pre-treatment with probiotic Escherichia coli strain Nissle 1917 completely eliminated signs of secretory diarrhoea in infected piglets (Schroeder et al., 2006). Non-avirulent Escherichia coli was also shown to reduce PWD and conserve a low intestinal coliform diversity in piglets that were environmentally exposed to three strains of pathogenic E. coli, namely E. coli (O147; K89, STb), E. coli O141 (K85, STb, VT2) and E. coli O149 (K91, K88, STa, STb, LT) (Melin \& Wallgren, 2002). A symbiotic combination of raw potato starch and probiotic E. coli strains, UM-2 and UM-7, led to reduced diarrhoea incidence, increased gut microbial diversity and conferred beneficial effects on growth performance in weaned piglets that were experimentally challenged with pathogenic E. coli K88 (Krause et al., 2010). Furthermore, liquid metabolic combinations of five strains of Lactobacillus fermentum $\left(T L_{1}, R G_{11}, R I_{11}, R G_{14}\right.$ and $R S_{5}$ ) were fed to weaned piglets, After five weeks, the results showed reduced incidences of diarrhoea and increased counts of faecal $L A B$, irrespective of the combinations (0.3\% metabolite of $T L_{1}, R G_{11}$ and $R I_{11}$ or $T L_{1}, R G_{14}$ and $R S_{5}$ strains, or $\mathrm{RG}_{11}, \mathrm{RG}_{14}$ and $\mathrm{RI}_{11}$ strains) (Thu et al., 2011). However, they reported no significant difference $(P>0.05)$ in average daily gain between the treatment and control piglets. In a comparative study, dietary probiotic containing strains of Bacillus licheniformis- $1.5 \times 10^{10} \mathrm{CFU} / \mathrm{g}$ and $0.3 \times 10^{10} \mathrm{CFU} / \mathrm{g}$ Saccharomyces cerevisiae, and an antibiotic (zinc bacitracin 10\%, $50 \mathrm{mg} / \mathrm{kg}$ of colistin sulphate 10\%, and $100 \mathrm{mg} / \mathrm{kg}$ olaquindox 5\%) were used independently in two experiments to test their effect on attenuation of intestinal damage and nutrient digestibility after enterotoxigenic E. coli K88 challenge in weaned piglets. The results showed that both probiotics and antibiotics decreased $(P<0.05)$ diarrhoea, and improved average daily intake and average daily gain in the weaned piglets. Hence, they showed that probiotics could be potential alternatives to in-feed antibiotics (Pan et al., 2017).

Although a number of published studies point to the positive effects of probiotic supplementation on the reduction of PWD and improving the production performance indices in pigs, few no-response studies are published, and in most cases these are probably not published at all (Dubreuil, 2017). Trevisi et al. (2011) reported contrasting results to those by Zhang et al. (2010) on the effects of Lactobacillus rhamnosus GG ATCC 53103 in weaned piglets. Trevisi and colleagues showed that dietary supplementation of weaner diets with LGG had neither preventative nor control properties on the adverse effects of enterotoxigenic E. coli O149: F4ac. In detail, LGG supplementation after E. coli challenge did not reduce the incidence of diarrhoea or the number of $\mathrm{E}$. coli shade in faeces. There was no significant difference in total lactic acid bacteria, enterobacteria and yeast compared with the control, while ETEC numbers tended to increase with LGG. In another study by Zhou et al. (2015), F4 receptor - negative (F4R-) crossbred piglets (Landrace $\times$ Yorkshire $\times$ Duroc) were orally administered with low and high doses of the probiotic combination, Bacillus licheniformis (DSM 5749) and Bacillus subtilis (DSM 5750)-BLS-mix, for seven days preceding F4 (K88) - positive ETEC/VTEC/EPEC challenge. The results showed no difference in diarrhoea incidence among the treatments groups. However, the probiotic mixture ameliorated the enteritis symptoms. Furthermore, their data indicated that BLS-mix increases the generation of CD4 ${ }^{+} \mathrm{IL}-10 \mathrm{~T}$ cells during active inflammation of the intestinal tract owing to pathogenic bacteria, but this might actually prohibit clearance of the pathogen. Also, although consumption of BLS-mix induced IL-10 producing Tr1 cells, this alone cannot account for protection of weaned piglets from $\mathrm{F}^{+}$ETEC/VTEC/EPEC infection. Additionally, neither low nor high dose BLS-mix had a significant influence on daily feed intake and average daily gain in comparison with the control. For seven days Maneewan et al. (2011) hand-fed three-way crossbred piglets $10 \mathrm{~mL}$ of Bacillus subtilis MP9 and MP10 $\left(10^{11} \mathrm{CFU} / \mathrm{mL}\right)$ per day. The results of their study revealed no significant $(P>0.05)$ difference in diarrhoea scores between the probiotic and control groups, except for shortened diarrhoea periods in the MP9 and MP10 groups. In a study to investigate the effect of crowding stress and ETEC K88 challenge in nursery piglets, researchers showed that reduction in space allowance and ETEC challenge caused detrimental effects to some immunological and performance parameters, and increased E. coli numbers, and that probiotic supplementation with E. coli UM-2 and UM-7 had few positive effects in ameliorating these parameters (Nyachoti et al., 2014).

\section{Mechanisms of Action of Probiotics}

Several researchers and reviewers have documented probable mechanisms through which probiotics confer their effects to the host (Boirivant \& Strober, 2007; Vondruskova et al., 2010; Brown, 2011; Cho et al., 
2011; Bermudez-Brito et al., 2012; Bajaj et al., 2015). The ability of probiotics to effect their mechanisms on the swine gut is highly dependent on whether they can tolerate the gastric and bile secretions as they descend along the upper intestinal tract (Bajaj et al., 2015). The caecum and colon are target sites for probiotic activity since they harbour diverse and dense populations of microorganisms and thus, once ingested, probiotics modulate the balance and activity of the gut microbiome (Chaucheyras-Durand \& Durand, 2009). Probiotics are believed to improve the host health through increasing the abundance of commensal microflora in the gut (Chaucheyras-Durand \& Durand, 2009). Although the exact modes of action of probiotics on the host gut are still unclear (Wohlgemuth et al., 2010), probable mechanisms have been suggested and demonstrated, such as modulation of gut microbiota, effects on nutrient digestibility and absorption, modulation of the host immune system, secretion of antimicrobial compounds and reduction of diarrhoea (Chaucheyras-Durand \& Durand, 2009; Brown, 2011; Bajaj et al., 2015; Do et al., 2017; Sánchez et al., 2017). Some of these probiotic mechanisms may be strain specific (Boirivant \& Strober, 2007). However, the authors summarized some important aspects from the literature pertaining to probiotic modulation of the swine immune system in the next subchapter, because they are of interest and value to the current study.

\section{Probiotics Modulation of the Immune System}

Germ-free animals can grow adequately without the contribution of the gut microbiota. However, in the absence of microbial colonization, these animals remain functionally immature in certain bodily systems, for example the mucosal and systemic immune system, the development of the secondary lymphoid tissues and response and susceptibility to pathogenic microorganisms (Roselli et al., 2017). This phenomenon thus provides a basis for demonstrating the relationship between gut microbiota colonization (with symbiotic bacteria) and their diversification with the maturation of the immune system. The gut has a larger endowment of lymphocytes than any other organ in the body, and is thus regarded as the largest body immune organ (Brown, 2011). The intestinal enterocytes provide a protective barrier against passive loss of nutrients and also block the entry of pathogens into the body system, revealing how the innate and adaptive immune systems in the intestines are closely integrated with other intestinal functions such as absorption (Bron et al., 2011; Brown, 2011). In addition, the GIT lumen and the upper part of its mucous layer harbour a large population of microorganisms whose composition affects the epithelial barrier and immune system functionality. Probiotic bacteria modulate the immune system directly through adjusting the secretion of immunoglobulins or cytokines, increasing the activity of macrophages or natural killer cells, or through indirect mechanisms such as enhancing the gut epithelial barrier, and altering the mucus secretion or through competitive exclusion of other pathogenic bacteria (La Fata et al., 2017). Immunoglobulins A and G are among those whose production and circulation can be stimulated by probiotic bacteria (Vondruskova et al., 2010; Bajaj et al., 2015). Probiotics elevate the function of phagocytic action and increase the phagocytic receptor expression in the neutrophils of an individual. Lactobacillus plantarum elevates antibody production against pathogenic Escherichia coli while Bifidobacterium longum and other LAB increase the numbers of Immunoglobulin A (IgA) (Scharek et al., 2005). Several studies have documented the influence of probiotic supplementation in pigs on the functionality and response of the immune system (see Table 4).

Among other functions of the gut, the epithelium creates a physical barrier between the external environment and the host's immune system, which makes its functionality and integrity paramount in aiding permeability to nutrients and other important micro molecules, in addition to protecting the host from aberrant pathogens. Multi-protein complexes, which are referred to as tight junctions (TJs), are responsible for maintaining the integrity of the gut epithelium (Lee, 2015). Compounds that have been demonstrated to regulate the expression of TJs include probiotics. These have been shown to regulate the expression and localization of the tight TJs (La Fata et al., 2017). Various probiotics strains, including Escherichia coli Nissle 1917, Lactobacillus rhamnosus GG, Lactobacillus casei DN-114001 and Lactobacillus plantarum MB452, have been shown to improve the gut epithelial barrier function through modulation mechanisms on the TJs (Parassol et al., 2005; Ukena et al., 2007; Johnson-Henry et al., 2008; Anderson et al., 2010). These probiotics modulate the TJs via upregulation of the Zona occludens $(1,2,3)$, and other tight junctionassociated proteins. Up-regulation of ZO-1 is believed to stabilize the TJs and therefore improve the barrier function of the gut epithelium (La Fata et al., 2017). 
Table 4 Influence of probiotics on the immune system in swine

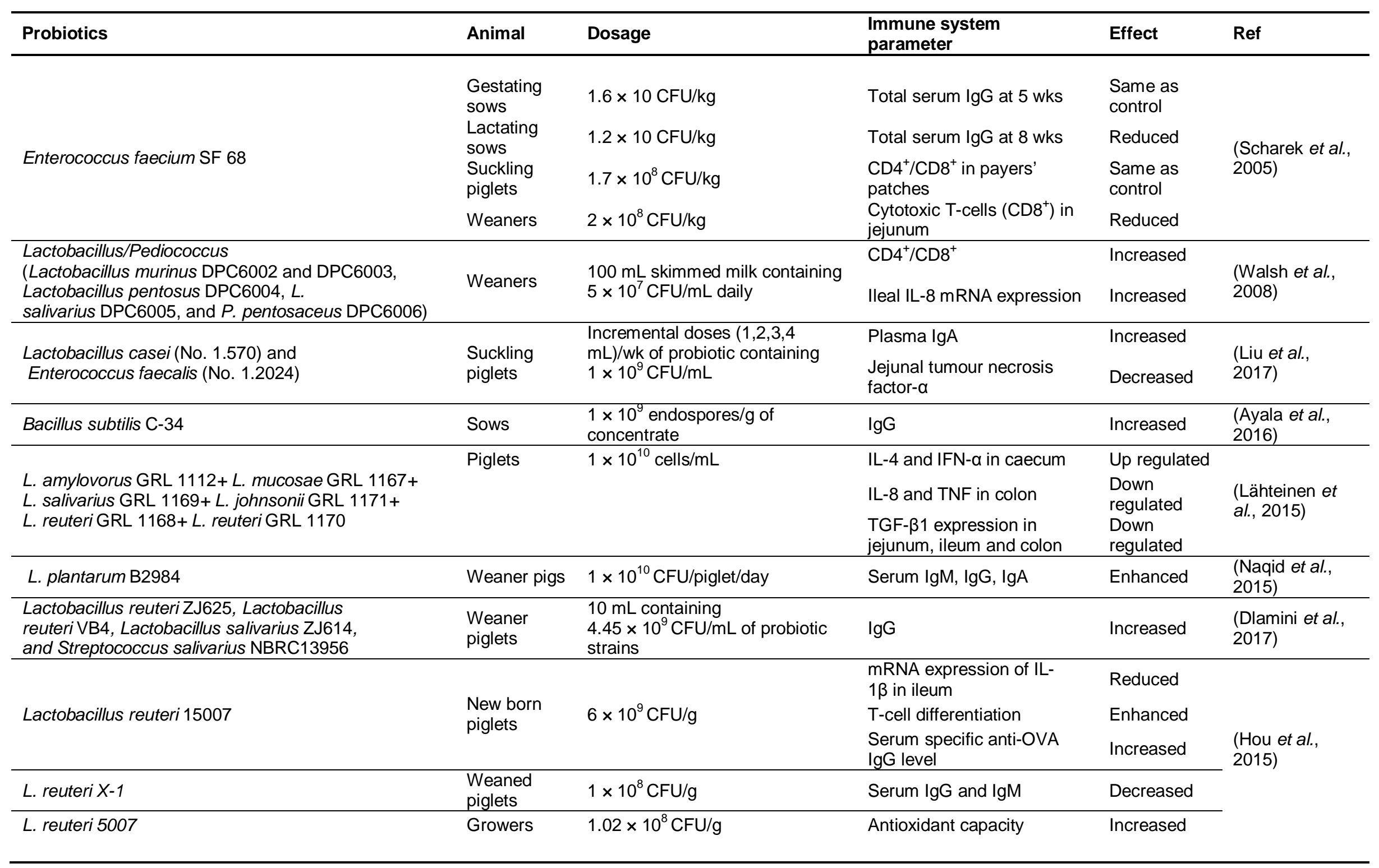

CFU: Colony forming unit, IgG: Immunoglobulin G, IgM: Immunoglobulin M, TNF: Tumour necrosis factor, IL: Interleukin, IFN: Interferon, wks: weeks 


\section{Conclusion}

It is evident that wide and increasing lists of probiotics have been studied and tested for their ability to prevent PWD in pigs, and consequently are fronted as potential alternatives to antibiotics. The majority of the microorganisms used as probiotics in the studies belong to - but are not limited to - the genera Lactobacilli, Bacillus, Bifidobacterium, Enterococcus, probiotic Escherichia coli and Saccharomyces. These probiotic strains can be given as single concoctions or in combination. Generally, probiotic feeding may be a better alternative to treating $\mathrm{E}$. coli induced diarrhoea than antibiotic feed additives. However, there is a need to standardize supplementation protocols, including dosage, onset and duration of treatment for each probiotic strain. The authors suggest that more field studies in more natural and commercial farm settings should be conducted to augment the literature in relation to the use of probiotics as alternatives to antibiotics in treating PWD.

\section{Acknowledgements}

This research was supported by a grant from the Next-Generation BioGreen 21 Program(PJ01322302), Rural Development Administration, Republic of Korea.

\section{Authors' Contribution}

All authors contributed equally to sourcing the materials and writing the final copy of the manuscript.

\section{Conflict of Interest declaration}

The authors declare no conflict of interest.

\section{References}

Additives, E. P. o. , \& Feed, P. o. S. u. i. A., 2011. Scientific opinion on the safety and efficacy of BioPlus 2B (Bacillus licheniformis DSM 5749 and Bacillus subtilis DSM 5750) as a feed additive for sows. EFSA Journal 9, 2356.

Alexopoulos, C., Georgoulakis, I.E., Tzivara, A., Kyriakis, C.S., Govaris, A. \& Kyriakis, S.C., 2004. Field evaluation of the effect of a probiotic-containing Bacillus licheniformis and Bacillus subtilis spores on the health status, performance, and carcass quality of grower and finisher pigs. J. Vet. Med. A. Physiol. Pathol. Clin. Med. 51, 1439-0442.

Anderson, R.C., Cookson, A.L., McNabb, W.C., Park, Z., McCann, M.J., Kelly, W.J. \& Roy, N.C., 2010. Lactobacillus plantarum MB452 enhances the function of the intestinal barrier by increasing the expression levels of genes involved in tight junction formation. BMC Microbiology 10, 316.

Ayala, L., Bocourt, R., Castro, M., Martínez, M. \& Herrera, M., 2016. Effect of the probiotic additive Bacillus subtilis and their endospores on milk production and immune response of lactating sows. Cuban J. Agric. Sci. 49, 71-74.

Badia, R., Brufau, M.T., Guerrero-Zamora, A.M., Lizardo, R., Dobrescu, I., Martin-Venegas, R., Ferrer, R., Salmon, H., Martínez, P. \& Brufau, J., 2012. ß-galactomannan and Saccharomyces cerevisiae var. Boulardii modulate immune response against Salmonella enterica ser. Typhimurium in porcine intestinal epithelial and dendritic cells. Clin. Vaccine Immunol. 19 (3), 368-376

Bajaj, B.K., Claes, I.J.J. \& Lebeer, S., 2015. Functional mechanisms of probiotics. J. Microbiol. Biotechnol. Food Sci. 04, 321-327.

Barba-Vidal, E., Castillejos, L., Roll, V.F., Cifuentes-Orjuela, G., Moreno Muñoz, J.A. \& Martín-Orúe, S.M., 2017. The probiotic combination of Bifidobacterium longum subsp. infantis CECT 7210 and Bifidobacterium animalis subsp. lactis BPL6 reduces pathogen loads and improves gut health of weaned piglets orally challenged with Salmonella typhimurium. Front. Microbiol. 8, 1570.

Bermudez-Brito, M., Plaza-Díaz, J., Muñoz-Quezada, S., Gómez-Llorente, C. \& Gil, A., 2012. Probiotic mechanisms of action. Ann. Nutr. Metab. 61, 160-174.

Bird, A.R., Vuaran, M., Crittenden, R., Hayakawa, T., Playne, M.J., Brown, I.L. \& Topping, D.L., 2009. Comparative effects of high-amylose starch and a fructooligosaccharide on fecal bifidobacteria numbers and short-chain fatty acids in pigs fed Bifidobacterium animalis. Digestive Diseases and Sciences 54, 947-954.

Boirivant, M. \& Strober, W., 2007. The mechanism of action of probiotics. Curr. Opin. Gastroenterol. 23, 679-692.

Bron, P.A., van Baarlen, P. \& Kleerebezem, M., 2011. Emerging molecular insights into the interaction between probiotics and the host intestinal mucosa. Nature Reviews: Microbiology 10, 66-78.

Brown, M., 2011. Modes of action of probiotics: Recent developments. J. Anim. Vet. Adv. 10, 1895-1900.

Brown, I., Warhurst, M., Arcot, J., Playne, M., Illman, R.J. \& Topping, D.L., 1997. Fecal numbers of bifidobacteria are higher in pigs fed Bifidobacterium longum with high amylose cornstarch than with low amylose cornstarch. J. Nutr. 127, 1822-1827.

Callaway, T.R., Edrington, T.S., Anderson, R.C., Harvey, R.B., Genovese, K.J., ..., Nisbet, D.J., 2008. Probiotics, prebiotics and competitive exclusion for prophylaxis against bacterial disease. Anim. Health Res. Rev. 9, $217-225$.

Casey, P.G., Gardiner, G.E., Casey, G., Bradshaw, B., Lawlor, P.G., ..., Hill, C., 2007. A five-strain probiotic combination reduces pathogen shedding and alleviates disease signs in pigs challenged with Salmonella enterica Serovar typhimurium. Appl. Environ. Microbiol. 73, 1858-1863.

Chaucheyras-Durand, F. \& Durand, H., 2009. Probiotics in animal nutrition and health. Beneficial Microbes 1, 3-9.

Chen, Y.J., Kwon, O.S., Min, B.J., Son, K.S., Cho, J.H., Hong, J.W. \& Kim, I.H., 2005. The effects of dietary Biotite V supplementation as an alternative substance to antibiotics in growing pigs. Asian-Austral. J. Anim. Sci. 18, 16421645. 
Cho, J.H., Zhao, P.Y. \& Kim, I.H., 2011. Probiotics as a dietary additive for pigs: A review. J. Anim. Vet. Advances 10, 2127-2134.

Daudelin, J.-F., Lessard, M., Beaudoin, F., Nadeau, É., Bissonnette, N., Boutin, Y., Brousseau, J.-P., Lauzon, K. \& Fairbrother, J.M., 2011. Administration of probiotics influences F4 (K88)-positive enterotoxigenic Escherichia coli attachment and intestinal cytokine expression in weaned pigs. Vet. Res. 42, 69.

Dlamini, Z., Langa, R., Aiyegoro, O. \& Okoh, A., 2017. Effects of probiotics on growth performance, blood parameters, and antibody stimulation in piglets. S. Afr. J. Anim. Sci. 47, 766-775.

Do, J., Zafar, H. \& Saier Jr., M.H., 2017. Comparative genomics of transport proteins in probiotic and pathogenic Escherichia coli and Salmonella enterica strains. Microb. Pathogen. 107, 106-115.

Dong, G. \& Pluske, J., 2007. The low feed intake in newly-weaned pigs: Problems and possible solutions. Asian-Austral. J. Anim. Sci. 20, 440-452.

Dowarah, R., Verma, A. \& Agarwal, N., 2017. The use of Lactobacillus as an alternative to antibiotic growth promoters in pigs: A review. Anim. Nutr. 3, 1-6.

Dowarah, R., Verma, A.K., Agarwal, N., Patel, B.H.M. \& Singh, P., 2017. Effect of swine based probiotic on performance, diarrhoea scores, intestinal microbiota and gut health of grower-finisher crossbred pigs. Livest. Sci. 195, 74-79.

Dubreuil, J.D., 2017. Enterotoxigenic Escherichia coli and probiotics in swine: What the bleep do we know? Bioscience of Microbiota, Food, and Health 36, 75-90.

Duncker, S.C., Lorentz, A., Schroeder, B., Breves, G. \& Bischoff, S.C., 2006. Effect of orally administered probiotic E. coli strain Nissle 1917 on intestinal mucosal immune cells of healthy young pigs. Vet. Immunol. Immunopathol. $111,239-250$

Estrada, A., Drew, M.D. \& Van Kessel, A., 2001. Effect of the dietary supplementation of fructooligosaccharides and Bifidobacterium longum to early-weaned pigs on performance and fecal bacterial populations. Can. J. Anim. Sci. $81,141-148$.

Fairbrother, J.M., Nadeau, É. \& Gyles, C.L., 2005. Escherichia coli in postweaning diarrhea in pigs: An update on bacterial types, pathogenesis, and prevention strategies. Anim. Health Res. Rev. 6, 17-39.

FAO, 2016. Probiotics in animal nutrition - Production, impact, and regulation: by Bajagai, Y.S., Klieve, A.V. Dart, P.J. \& Bryden, W.L. Ed. P.S. Harinder. FAO Animal Production and Health Paper No. 179. FAO, Rome.

Frydendahl, K., 2002. Prevalence of serogroups and virulence genes in Escherichia coli associated with postweaning diarrhoea and edema disease in pigs and a comparison of diagnostic approaches. Vet. Microbiol. 85, 169-182.

Frydendahl, K., Jensen, T.K., Andersen, J.S., Fredholm, M. \& Evans, G., 2003. Association between the porcine Escherichia coli F18 receptor genotype and phenotype and susceptibility to colonization and postweaning diarrhea caused by E. coli O138: F18. Vet. Microbiol. 93, 39-51.

Gebert, S., Davis, E., Rehberger, T. \& Maxwell, C., 2011. Lactobacillus brevis strain 1E1 administered to piglets through milk supplementation prior to weaning maintains intestinal integrity after the weaning event. Beneficial Microbes 2 , 35-45.

Giang, H.H., Viet, T.Q., Ogle, B. \& Lindberg, J.E., 2010. Growth performance, digestibility, gut environment and health status in weaned piglets fed a diet supplemented with potentially probiotic complexes of lactic acid bacteria. Livest. Sci. 129, 95-103.

Giang, H.H., Viet, T.Q., Ogle, B. \& Lindberg, J.E., 2011. Effects of supplementation of probiotics on the performance, nutrient digestibility and faecal microflora in growing-finishing pigs. Asian-Austral. J. Anim. Sci. 24, 655-661.

Giang, H.H., Viet, T.Q., Ogle, B. \& Lindberg, J.E., 2012. Growth performance, digestibility, gut environment and health status in weaned piglets fed a diet supplemented with a complex of lactic acid bacteria alone or in combination with Bacillus subtilis and Saccharomyces boulardii. Livest. Sci. 143, 132-141.

Gresse, R., Chaucheyras-Durand, F., Fleury, M.A., Van de Wiele, T., Forano, E. \& Blanquet-Diot, S., 2017. Gut microbiota dysbiosis in postweaning piglets: understanding the keys to health. Trends in Microbiology 25, 851-873.

Guo, X., Li, D., Lu, W., Piao, X. \& Chen, X., 2006. Screening of Bacillus strains as potential probiotics and subsequent confirmation of the in vivo effectiveness of Bacillus subtilis MA139 in pigs. Antonie Van Leeuwenhoek 90, $139-146$.

Heo, J., Opapeju, F., Pluske, J., Kim, J., Hampson, D. \& Nyachoti, C., 2013. Gastrointestinal health and function in weaned pigs: a review of feeding strategies to control post-weaning diarrhoea without using in-feed antimicrobial compounds. J. Anim. Physiol. Anim. Nutr. 97, 207-237.

Heo, J., Shin, D., Chang, S.Y., Bogere, P., Park, M.R., Ryu, S., ..., Kim, Y., 2018. Comparative genome analysis and evaluation of probiotic characteristics of Lactobacillus plantarum Strain JDFM LP11. Korean Journal for Food Science of Animal Resources 38, 878.

Hong, T., Linh, N., Ogle, B. \& Lindberg, J.E., 2006. Survey on the prevalence of diarrhoea in pre-weaning piglets and on feeding systems as contributing risk factors in smallholdings in Central Vietnam. Trop. Anim. Health Prod. 38, 397-405.

Hou, C., Zeng, X., Yang, F., Liu, H., \& Qiao, S., 2015. Study and use of the probiotic Lactobacillus reuteri in pigs: A review. J. Anim. Sci. Biotechnol. 6, 14.

Huang, C., Qiao, S., Li, D., Piao, X. \& Ren, J., 2004. Effects of lactobacilli on the performance, diarrhea incidence, VFA concentration and gastrointestinal microbial flora of weaning pigs. Asian-Austral. J. Anim. Sci. 17, 401-409.

Jayaraman, B. \& Nyachoti, C.M., 2017. Husbandry practices and gut health outcomes in weaned piglets: A review. Anim. Nutr. 3, 205-211.

Johnson-Henry, K., Donato, K., Shen-Tu, G., Gordanpour, M. \& Sherman, P., 2008. Lactobacillus rhamnosus strain GG prevents enterohemorrhagic Escherichia coli O157: H7-induced changes in epithelial barrier function. Infection and Immunity $76,1340-1348$. 
Krause, D., Bhandari, S., House, J. \& Nyachoti, C., 2010. Response of nursery pigs to a synbiotic preparation of starch and an anti-Escherichia coli K88 probiotic. Appl. Environ. Microbiol. 76, 8192-8200.

Kyriakis, S., Tsiloyiannis, V., Vlemmas, J., Sarris, K., Tsinas, A., Alexopoulos, C. \& Jansegers, L., 1999. The effect of probiotic LSP 122 on the control of post-weaning diarrhoea syndrome of piglets. Res. Vet. Sci. 67, 223-228.

La Fata, G., Weber, P. \& Mohajeri, M.H., 2017. Probiotics and the gut immune system: Indirect regulation. Probiotics and Antimicrobial Proteins 1-11.

Lähteinen, T., Lindholm, A., Rinttilä, T., Junnikkala, S., Kant, R., ..., Jakava-Viljanen, M., 2014. Effect of Lactobacillus brevis ATCC 8287 as a feeding supplement on the performance and immune function of piglets. Vet. Immunol. Immunopath. 158, 14-25.

Lähteinen, T., Rinttilä, T., Koort, J.M., Kant, R., Levonen, K., Jakava-Viljanen, M., Björkroth, J. \& Palva, A., 2015. Effect of a multispecies lactobacillus formulation as a feeding supplement on the performance and immune function of piglets. Livest. Sci. 180, 164-171.

Laine, T.M., Lyytikäinen, T., Yliaho, M. \& Anttila, M., 2008. Risk factors for post-weaning diarrhoea on piglet producing farms in Finland. Acta Vet. Scan. 50, 21.

Lalles, J.-P., Bosi, P., Smidt, H. \& Stokes, C.R., 2007. Nutritional management of gut health in pigs around weaning. Proc. Nutr. Soc. 66, 260-268.

Lallès, J.P.P.B., Hauke, S. \& Chris, R.S., 2007. Weaning-A challenge to gut physiologists. Livest. Sci. 108, 82-93.

Lauridsen, C., 2017. A critical review on alternatives to antibiotics and pharmacological zinc for prevention of diarrhoea in pigs post-weaning. Rapport og Vidensyntese, DCA. 26.

Lee, S., Ingale, S., Kim, J., Kim, K., Lokhande, A., Kim, E., Kwon, I., Kim, Y. \& Chae, B., 2014. Effects of dietary supplementation with Bacillus subtilis LS 1-2 fermentation biomass on growth performance, nutrient digestibility, cecal microbiota and intestinal morphology of weanling pig. Anim. Feed Sci. Technol. 188, 102-110.

Lee, S.H., 2015. Intestinal permeability regulation by tight junction: implication on inflammatory bowel diseases. Intestinal Research 13, 11-18.

Liao, S.F. \& Nyachoti, M., 2017. Using probiotics to improve swine gut health and nutrient utilization. Anim. Nutr. 3, 331-343.

Liu, C., Zhu, Q., Chang, J., Yin, Q., Song, A., Li, Z., Wang, E. \& Lu, F., 2017. Effects of Lactobacillus casei and Enterococcus faecalis on growth performance, immune function and gut microbiota of suckling piglets. Arch. Anim. Nutr. 71, 120-133.

Liu, H., Zhang, J., Zhang, S., Yang, F., Thacker, P.A., Zhang, G., Qiao, S. \& Ma, X., 2014. Oral administration of Lactobacillus fermentum 15007 favors intestinal development and alters the intestinal microbiota in formula-fed piglets. J. Agric. Food Chem. 62, 860-866.

Lojanica, M., Manojlović, M., Jeremić, D. \& Petronijević, S., 2010. The effects of probiotic Enterococcus faecium DSM 7134 in the weaned pigs nutrition. Biotechnol. Anim. Husb. 26, 57-64.

Madec, F., Bridoux, N., Bounaix, S., Cariolet, R., Duval-Iflah, Y., Hampson, D.J. \& Jestin, A., 2000. Experimental models of porcine post-weaning colibacillosis and their relationship to post-weaning diarrhoea and digestive disorders as encountered in the field. Vet. Microbiol. 72, 295-310.

Maneewan, C., Yamauchi, K.-E., Thirabunyanon, M., Siri, S., Mekbungwan, A. \& Thongwittaya, N., 2011. Development of Bacillus subtilis MP and effective utilization on productivity and microorganisms in feces of suckling piglets. Int. J. Appl. Res. Vet. Med. 9, 382.

Melin, L. \& Wallgren, P., 2002. Aspects on feed related prophylactic measures aiming to prevent postweaning diarrhoea in pigs. Acta Vet. Scan. 43, 231.

Merrifield, C.A., Lewis, M.C., Claus, S.P., Pearce, J.T.M., Cloarec, O., ..., Rezzi, S., 2013. Weaning diet induces sustained metabolic phenotype shift in the pig and influences host response to Bifidobacterium lactis NCC2818. Gut 62, 842-851.

Mizumachi, K., Aoki, R., Ohmori, H., Saeki, M. \& Kawashima, T., 2009. Effect of fermented liquid diet prepared with Lactobacillus plantarum LQ80 on the immune response in weaning pigs. Animal 3, 670-676.

Nagy, B. \& Fekete, P.Z., 1999. Enterotoxigenic Escherichia coli (ETEC) in farm animals. Vet. Res. 30, $259-284$.

Naqid, I.A., Owen, J.P., Maddison, B.C., Gardner, D.S., Foster, N., Tchórzewska, M.A., La Ragione, R.M. \& Gough, K.C., 2015. Prebiotic and probiotic agents enhance antibody-based immune responses to Salmonella typhimurium infection in pigs. Anim. Feed Sci. Technol. 201, 57-65.

Nyachoti, C.M., Krause, D.O., Munyaka, P.M., Khafipour, E. \& Rodriguez-Lecompte, J.C., 2014. Effect of crowding stress and Escherichia coli K88+ challenge in nursery pigs supplemented with anti-Escherichia coli K88+ probiotics. J. Anim. Sci. 92, 2017-2029.

Omonijo, F.A., Ni, L., Gong, J., Wang, Q., Lahaye, L. \& Yang, C., 2017. Essential oils as alternatives to antibiotics in swine production. Anim. Nutr. 4, 126-136.

Pan, L., Zhao, P., Ma, X., Shang, Q., Xu, Y., Long, S., Wu, Y., Yuan, F. \& Piao, X., 2017. Probiotic supplementation protects weaned pigs against enterotoxigenic Escherichia coli K88 challenge and improves performance similar to antibiotics. J. Anim. Sci. 95, 2627-2639.

Papatsiros, V., Tassis, P., Tzika, E., Papaioannou, D., Petridou, E., Alexopoulos, C. \& Kyriakis, S., 2011. Effect of benzoic acid and a combination of benzoic acid with a probiotic containing Bacillus Cereus var. toyoi in weaned pig nutrition. Polish J. Vet. Sci. 14, 117-125.

Parassol, N., Freitas, M., Thoreux, K., Dalmasso, G., Bourdet-Sicard, R. \& Rampal, P., 2005. Lactobacillus casei DN-114 001 inhibits the increase in paracellular permeability of enteropathogenic Escherichia coli-infected T84 cells. Res. Microbiol. 156, 256-262. 
Pieper, R., Hackl, W., Korn, U., Zeyner, A., Souffrant, W. \& Pieper, B., 2011. Effect of ensiling triticale, barley and wheat grains at different moisture content and addition of Lactobacillus plantarum (DSMZ 8866 and 8862) on fermentation characteristics and nutrient digestibility in pigs. Anim. Feed Sci. Technol. 164, 96-105.

Priori, D., Fontanesi, L., Colombo, M., Bosi, P., Latorre, R., ..., D'Inca, R., 2015. Comparison of three patterns of feed supplementation with live Saccharomyces cerevisiae yeast on postweaning diarrhea, health status, and blood metabolic profile of susceptible weaning pigs orally challenged with Escherichia coli F4ac1. J. Anim. Sc. 93, 2225-2233.

Reid, G. \& Friendship, R., 2002. Alternatives to antibiotic use: probiotics for the gut. Anim. Biotechnol. 13, 97-112.

Rhouma, M., Fairbrother, J.M., Beaudry, F. \& Letellier, A., 2017. Postweaning diarrhea in pigs: risk factors and noncolistin-based control strategies. Acta Vet. Scan. 59, 31.

Riboulet-Bisson, E., Sturme, M.H., Jeffery, I.B., O'Donnell, M.M., Neville, B.A., ..., Ross, R.P., 2012. Effect of Lactobacillus salivarius bacteriocin Abp118 on the mouse and pig intestinal microbiota. PLoS one 7, e31113.

Roselli, M., Finamore, A., Britti, M.S., Bosi, P., Oswald, I. \& Mengheri, E., 2005. Alternatives to in-feed antibiotics in pigs: Evaluation of probiotics, zinc or organic acids as protective agents for the intestinal mucosa. A comparison of in vitro and in vivo results. Anim. Res. 54, 203-218.

Roselli, M., Pieper, R., Rogel-Gaillard, C., de Vries, H., Bailey, M., Smidt, H. \& Lauridsen, C., 2017. Immunomodulating effects of probiotics for microbiota modulation, gut health and disease resistance in pigs. Anim. Feed Sci. Technol. 233, 104-119.

Sánchez, B., Delgado, S., Blanco-Míguez, A., Lourenço, A., Gueimonde, M. \& Margolles, A., 2017. Probiotics, gut microbiota, and their influence on host health and disease. Mol. Nutr. Food Res. 61, 1600240.

Scharek, L., Guth, J., Reiter, K., Weyrauch, K., Taras, D., Schwerk, P., Schierack, P., Schmidt, M., Wieler, L. \& Tedin, K., 2005. Influence of a probiotic Enterococcus faecium strain on development of the immune system of sows and piglets. Vet. Immun. Immunopath. 105, 151-161.

Schroeder, B., Duncker, S., Barth, S., Bauerfeind, R., Gruber, A., Deppenmeier, S. \& Breves, G., 2006. Preventive effects of the probiotic Escherichia coli strain Nissle 1917 on acute secretory diarrhea in a pig model of intestinal infection. Diges. Dis. Sci. 51, 724-731.

Shu, Q., Qu, F. \& Gill, H.S., 2001. Probiotic treatment using Bifidobacterium lactis HN019 reduces weanling diarrhea associated with rotavirus and Escherichia coli infection in a piglet model. J. Ped. Gastroent. Nutr. 33, 171-177.

Suo, C., Yin, Y., Wang, X., Lou, X., Song, D., Wang, X. \& Gu, Q., 2012. Effects of Lactobacillus plantarum ZJ316 on pig growth and pork quality. BMC Vet. Res. 8, 89.

Taras, D., Vahjen, W. \& Simon, O., 2007. Probiotics in pigs - modulation of their intestinal distribution and of their impact on health and performance. Livest. Sci. 108, 229-231.

Thu, T., Loh, T.C., Foo, H., Yaakub, H. \& Bejo, M., 2011. Effects of liquid metabolite combinations produced by Lactobacillus plantarum on growth performance, faeces characteristics, intestinal morphology and diarrhoea incidence in postweaning piglets. Trop. Anim. Health Prod. 43, 69-75.

Trevisi, P., Casini, L., Coloretti, F., Mazzoni, M., Merialdi, G. \& Bosi, P., 2011. Dietary addition of Lactobacillus rhamnosus GG impairs the health of Escherichia coli F4-challenged piglets. Animal 5, 1354-1360.

Ukena, S.N., Singh, A., Dringenberg, U., Engelhardt, R., Seidler, U., Hansen, W., Bleich, A., Bruder, D., Franzke, A. \& Rogler, G., 2007. Probiotic Escherichia coli Nissle 1917 inhibits leaky gut by enhancing mucosal integrity. PLoS one 2, e1308.

Vondruskova, H., Slamova, R., Trckova, M., Zraly, Z. \& Pavlik, I., 2010. Alternatives to antibiotic growth promoters in the prevention of diarrhoea in weaned piglets: A review. Vet. Med. 55, 199-224.

Walsh, M. C., Gardiner, G.E., Hart, O.M., Lawlor, P.G., Daly, M., Lynch, B., Richert, B.T., Radcliffe, S., Giblin, L. \& Hill, C., 2008. Predominance of a bacteriocin-producing Lactobacillus salivarius component of a five-strain probiotic in the porcine ileum and effects on host immune phenotype. FEMS Microbiol. Ecol. 64, 317-327.

Wang, S.-P., Yang, L., Tang, X.-S., Cai, L.-C., Liu, G., Kong, X.-F., Blachier, F. \& Yin, Y.-L., 2011. Dietary supplementation with high-dose Bacillus subtilis or Lactobacillus reuteri modulates cellular and humoral immunities and improves performance in weaned piglets. J. Food Agric. Environ. 9, 181-187.

Wellock, I., Fortomaris, P., Houdijk, J. \& Kyriazakis, I., 2007. Effect of weaning age, protein nutrition and enterotoxigenic Escherichia coli challenge on the health of newly weaned piglets. Livest. Sci. 108, 102-105.

Wohlgemuth, S., Loh, G. \& Blaut, M., 2010. Recent developments and perspectives in the investigation of probiotic effects. Int. J. Med. Microbiol. 300, 3-10.

Yi, H., Zhang, L., Gan, Z., Xiong, H., Yu, C., Du, H. \& Wang, Y., 2016. High therapeutic efficacy of Cathelicidin-WA against postweaning diarrhea via inhibiting inflammation and enhancing epithelial barrier in the intestine. Scientific Reports 6, 25679.

Zeyner, A. \& Boldt, E., 2006. Effects of a probiotic Enterococcus faecium strain supplemented from birth to weaning on diarrhoea patterns and performance of piglets. J. Anim. Physiol. Anim. Nutr. 90, 25-31.

Zhang, L., Xu, Y. Q., Liu, H.Y., Lai, T., Ma, J.L., Wang, J. F. \& Zhu, Y. H., 2010. Evaluation of Lactobacillus rhamnosus GG using an Escherichia coli K88 model of piglet diarrhoea: Effects on diarrhoea incidence, faecal microflora, and immune responses. Vet. Microbiol. 141, 142-148.

Zhao, P.Y. \& Kim, I.H., 2015. Effect of direct-fed microbial on growth performance, nutrient digestibility, fecal noxious gas emission, fecal microbial flora and diarrhea score in weanling pigs. Anim. Feed Sci. Technol. 200, 86-92.

Zhou, D., Zhu, Y.-H., Zhang, W., Wang, M.-L., Fan, W.-Y., Song, D., Yang, G.-Y., Jensen, B.B. \& Wang, J.-F., 2015. Oral administration of a select mixture of Bacillus probiotics generates Tr1 cells in weaned F4ab/acR- pigs challenged with an F4+ ETEC/VTEC/EPEC strain. Vet. Res. 46, 95. 